\title{
Vowel Harmony: An Historical Account
}

\author{
Emran R. Al Khattab*
}

Language Center at Al Hussein Bin Tala University, Jordan

Corresponding Author: Emran R. Al Khattab, E-mail: eqisho@yahoo.com

\section{ARTICLE INFO}

\section{Article history}

Received: December 15, 2017

Accepted: January 26, 2018

Published: February 28, 2018

Volume: 9 Issue: 1

Advance access: January 2018

Conflicts of interest: None

Funding: None

\begin{abstract}
All languages change over time. English has undergone continuous change throughout its three major periods: Old English (roughly from 450 to 1100 AD), Middle English (from 1100 to 1500), and Modern English (from 1500 to the present). Sound is one of the most easily influenced parts of language to be subject to different changes. Sound change is inevitable and it is a live indication of the continuous growth of language. The evidence to prove the regularity and systematicity of sound change has been the main concern of linguists, This paper seeks to provide more evidence on how vowel harmony played a key role on the regularity of sound change by extracting samples of sound changes that have taken place throughout the English history.
\end{abstract}

Key words:

Phonology,

Sound change,

Decay of inflections,

I-umlaut,

Vowel creation

\section{INTRODUCTION}

Sound change is perhaps the most thoroughly studied area in the subject of language change. Evidence in literature shows that languages and sounds, in particular, are subject to continuous change over time. No doubt, such processes are not unexpected since language change is a feature of all living languages all over the world. Research on this area has revealed that understanding the lexicon as well as the relationship among languages requires a comprehensive understanding of sound change. Furthermore, understanding sound change is a prerequisite to understanding linguistic reconstruction and loan words, and determining whether or not languages are related to one another.

As far as this paper is concerned, a deliberate attempt has been made to shed light on three main changes (primary phonological) in English attributed to phonological necessities. To this end, the paper addresses three different but related targets: (i) vowels and consonants created (added to the sound system) due to phonological necessities, (ii) the role of phonology on the decay of inflections and (iii) the role of phonology on segments and feature change.

As far as this study is concerned, the following three Research Questions have been considered:

- What are the vocalic and consonantal sounds added to the previously existing sound system of the language that are attributed to the phonetic environment necessity?

- To what extent does phonology influence the decay of inflections in English?

- To what extent does the phonological environment trigger feature and segment change?

\section{LITERATURE REVIEW}

English is one of the universal languages whose sound system definitely changes over time. Divergent definitions and opinions are revealed here to help us understand the three different kinds of sound change that are being dealt with in this study.

Campbell (1998) explains that " $i$-umlaut is a kind of sound change in which a back vowel is fronted when followed by a front vowel or/j/(usually in the next syllable). Umlaut initially created front vowel allophones of back vowels, which became phonemic when the final front vowel of the umlaut environment was lost.". Crystal (1995) provides further information and explanation on the role and origin of the $i-u m$ laut process of sound change "In Germanic there were many words when a vowel in a stressed syllable was immediately followed by a high short vowel [i] or a vowel like [j] in the next syllable. The quality of this high front sound caused by 
the preceding sound to change (mute). The process came to be called $i$-mutation or $i$-umlaut (a Germanic term meaning 'vowel alternation'). It is thought to have taken place during the $7^{\text {th }}$ century. There is no sign of the vowel continuity to change in this way in later periods. It is a kind of 'vowel harmony' which is a natural process that affects modern languages." It is quite obvious from Campbell's and Crystal's definitions of $i$-umlaut that it is a kind of vowel reduction triggered by the loss of the umlaut environment.

Katamba (1995) defines assimilation which is a phonological process that affects sound in a way that leads to creating new and similar sounds in all languages of the world as "assimilation is the most common type of sequential change, which has the effect of increasing the efficiency of articulation through a simplification of articulatory movements. Assimilation involves voicing, place, and manner of articulation.". Crowley (1992) provides further information about assimilation when defining it as "Assimilation is one sound becomes more similar to another, a change in a sound brought about the influence of a neighboring, usually an adjacent sound. Assimilatory changes are very common, and they are probably the most frequent and most important category of sound change.

Crosswhite. K (2001) states that vowel reduction and inflections decay are well-Known phonological phenomena: The idea that certain vowels might undergo qualitative changes in unstressed positions is likely familiar to anyone who has taken an introductory phonology course. Because these phenomena can be so succinctly described -i.e. "unstressed vowels undergo neutralization" it is often assumed that vowel reduction is a unitary phenomenon, with a single formal analysis". Barber, C. (1993) adds more details about the aspects and origins of vowel reduction and the loss of inflections: "The processes of change within the inflectional system commenced towards the end of the OE period when word -endings began to become less distinct. For example, by the end of the $11^{\text {th }}$ century and in most dialects, inflections such as $-a,-e,-u$, and -an had been uniformly reduced to -e, (pronounced [ $\partial]$ ). Another modification involved the loss of word -final $-n$ after $-e$ in unstressed syllable. Eventually the remaining -e itself was abandoned. For example, Middle English drinken (from OE drincan "to drink") became first drinke and then" drink".

\section{METHOD}

This study traces back the sound changes that have taken place in English explained previously. In doing so, four procedures have been employed:

- Extracting samples of sound changes that have taken place throughout the English history

- Classifying the extracted examples into three different types, which, in turn reflect the type of sound changes.

- Examining the reasons behind such changes

- Exploring the effect of phonology on these changes.

\section{RESULTS AND DISCUSSION}

In conformity with the aims posited above, this section is divided into three subsections: the first section sheds light on the reasons behind introducing new vocalic and consonantal sounds added to the English Language in later stages of its development. The second section illustrates the phonological impact on the decay of Old English inflections. The third section, on the other hand, spots light on the segments and feature change.

Section (1): Old English is one of the languages that had undergone numerous changes including the sound system. Old English had seven vowel letters ( $a, a e, e, I, o, u$, and $y$ ) representing long or short sounds, since vowel length was phonemic. It also had two long diphthongs (eo and ea).

This brief introduction is provided here to show that Old English did not have some vowels that appeared later in this period that were attributed to phonological necessities.

A phonological process called $i$-umlaut (vowel harmony) was the main reason for creating two new vowels in Old English, these two vowels were [o] and [y]. There was no need to these vowels which did not exist in early Old English, but later they had to appear due to the effect of one sound on another (usually in the next syllable).

Accordingly, this phenomenon will be explained and described by taking some examples from this period and tracing the changes that they underwent.

The first example of this change is the word fót:

Step (1): The word fót in Old English was pluralized by adding the suffix [i], so fót was singular and its plural was fóti.

Step (2): Adding this vowel as a plural sign caused a new vowel to occur taking one feature of the two sounds [ó] $\mathrm{m}$ and [i]. The vowel [ó] was [+ rounded, +back], and the vowel [i] was [ - rounded, + front]. Having these two vowels in the same word in different syllables led to a new vowel to be created which was $[\theta]$ whose features were $[+$ rounded, + front] as in fóti, this new vowel was created and introduced after being umlauted, while the singular fót remained having the original $[o]$.

Step 3: The vowel [i] - the plural sign - was lost in early Old English when inflections were lost leaving the umlauted vowel as the marker of the plural form.

Step (4): The new vowel [ $\theta]$ was later derounded by Middle English yielding [ī] and [ē] as in [fēt].

Step (5): Later in Modern English, [e] became [ee] as in the plural of foot (fót) which is feet (fêt).

The second example of this change is the word $m \bar{u} s$ from Old English too.

Step (1): The word $m \bar{u} s$ was pluralized by adding the suffix [i] as in $m \bar{u} s i$.

Step (2): Adding this vowel as a plural sign caused a new vowel to be created taking one feature from each of the two sounds[ū] and [i].

The vowel $[\overline{\mathrm{u}}]$ was $[+$ rounded, + back], and the vowel [i] was [+front, - rounded]. Having these two vowels in the same word in different syllables led to a new vowel to be created which was $[\bar{y}]$ whose features were $[+$ front, + rounded] as in the word $m \bar{y} s i$, this new vowel was created and introduced after being umlauted, while the singular form remained having the original vowel $[\overline{\mathrm{u}}]$.

Step (3): The vowel [i] - the plural sign - was lost when 
inflections were lost in Middle English leaving the umlauted vowel as the marker of the plural form.

Step (4): The new vowel $[\bar{y}]$ was derounded by Middle English yielding [ī] and [ē].

Step (5): Later in Modern English, the word $m \bar{y} s$ became to be written mice as an irregular plural for mouse.

The following table may provide extra and clear information to what has been said above:

\begin{tabular}{llll}
\hline Pre-OE1 & Pre-OE2 & $\begin{array}{l}\text { Early } \\
\text { OE }\end{array}$ & Subsequent Changes \\
\hline [g ós $]$ & {$[\mathrm{g}$ ós $]$} & {$[$ gós $]$} & {$[\mathrm{gu}: \mathrm{s}]$ 'goose' } \\
[g ósi $]$ & {$[\mathrm{g} \theta \mathrm{si}]$} & {$[\mathrm{g} \theta \mathrm{s}]$} & {$[\mathrm{gi}: \mathrm{s}]$ 'geese' } \\
{$[\mathrm{mūs}]$} & {$[\mathrm{mūs}]$} & {$[\mathrm{mūs}]$} & {$[$ maus] 'mouse' } \\
{$[\mathrm{mūsi}]$} & {$[\mathrm{mȳsi}]$} & {$[\mathrm{mȳs}]$} & {$[$ mais] 'mice' } \\
\hline
\end{tabular}

A careful examination of the history of the English language shows that several consonants had been inserted into some words due to phonetic necessities. The word empty, for instance, was emty in Old English. The reason behind inserting the sound $[\mathrm{p}]$ in this phonetic environment is attributed to a phonological process called anticipation whereby the articulators take the position of the following sound while producing a given sound. For this reason, the articulators here take the position of the sound $[\mathrm{t}]$ while producing $[\mathrm{m}]$.

The result is the production of a non-existing sound [p], which shares features of both [m] which is [+bilabial] and [t] which is [-voice]. This is, however, the very reason behind inserting such a consonant.

Section (2): Phonology gives us the answer and the explanation to the following question: Why did Old English inflectional endings decay? The most obvious explanation is that it became increasingly difficult to hear them, because of the way the words had become to be stressed during the evolution of the Germanic languages. The ancestor language of Germanic, Indo - European, had a free system of accentuation, in which the stress within a word moved to another syllable according to intricate rules. In Germanic, this system of accentuation changed, and most words came to carry the main stress of the first syllable. This is the system found in Old English.

Having the main stress at the beginning of a word can readily give rise to an auditory problem at the end. This is especially so when there are several endings which are phonetically very similar, such as -en, -on, and -an. In rapid conversational speech, it would have been difficult to distinguish them. This neutralization undoubtedly affected the Old English system.

Some examples are provided here to clarify this phenomenon that appeared in later Old English and the beginning of Middle English.

Old English foundan (Prêt. pl) along with foundan (past. part) became to be pronounced the same in Middle English as in founde(n), stressing the first syllable and having the same ending were two main reasons that led to the loss and decay of inflections. In this case the same vowel in the two words was reduced.

After reducing the vowel, the two different forms of the verb findan came to have the same pronunciation and spell- ing found leading to deleting the vowel [a] along with the consonant $[\mathrm{n}]$.

Another example of vowel reduction is the word satnas:

$$
\text { - Plural..........................stanas [a] }
$$$$
\text { Genitive .....................stanes [e] }
$$

In Old English, the word stanas used to be a plural form, with the marker [as], and the second word stanes used to be a form for the Genitive case with the marker [es]. In Middle English the stress moved to be on the first syllable causing the reduction of the vowels at the ends of the words. These two words became to be pronounced the same. What caused this similarity in pronunciation is the stress being on the first syllable of the word, then the two vowels [a] and [e] came to be pronounced as schwa [ə] as in the following words:

- $\quad$ Plural .........................stones [ə].

In Modern English, the two words became to be pronounced the same deleting the schwa vowel with a tiny difference in spelling, they became;

- $\quad$ Plural ........................stones ............ $\Phi$

Section (3): Phonology has been one of the most important factors that cause language change in general. It has the key role on feature and segment change of Old English. Here are some words selected to be explained and analyzed to clarify this phenomenon.

Assimilation is the first phonological process that affected Old English, and our first example is the word possible with the prefix in from Old English.

The prefix in was used to indicate negative forms. So, possible was positive and its negative form was inpossible. The/n/sound is [+nasal, +alveolar] while/p/is [+ plosive, +bilabial]. Later in Middle English and Modern English as well, the $/ \mathrm{n} /$ sound turned to be an $/ \mathrm{m} / \mathrm{sound}$. This is - of course for the sake of articulation. The $/ \mathrm{m} /$ sound shares some features with the $/ \mathrm{n} / \mathrm{and} / \mathrm{p} / \mathrm{sounds}$. The $/ \mathrm{m} /$ sound is [+bilabial, + nasal]. The new word has become impossible instead of inpossible.

In Modern English, there are many examples of this change that were derived from Old English such as irregular, illegal, and impossible. Overtime, the pronunciation has done away with the in and smoothed it into the leading sounds of the word, so that in becomes il, ir, or im depending on the situation. Such kind of assimilation is called regressive assimilation, because the second sound affects the first one.

Another example of this change is the phonological process epenthesis: The word ganra is our example from Old English. The two-underlined $n$ and $r$ are intervocalic - i.e. VnrV. Later in Old English, the sound/d/was inserted between these two letters. Over time, this word came to be written as gandra instead - i.e. VndrV.

The explanation of this change is that the $/ \mathrm{n} / \mathrm{sound}$ and the new sound/d/are alveolar, but the/d/sound agrees with the following segments in terms of voice and nasality. The/d/sound appeared here due to having the same place of articulation with the nasal sound/n/, and at the same time takes the features [+voice] and [+nasal] from the following 
sound. So, the/d/sound is the nearest sound to appear in the phonetic environment to serve as a bridge for the transition between segments on the other side. Later in Middle English and Modern English this word came to be written gander.

There are also many examples from Old English of this change as in the following table:

\begin{tabular}{llll}
\hline Word & $\begin{array}{l}\text { Letters } \\
\text { Intervocalically }\end{array}$ & Change & Later Form \\
\hline Ganra & VnrV & VndrV & Gandra 'gander' \\
Smile & VmlV & VmblV & Simble 'always' \\
\hline
\end{tabular}

A third example of this change is the change of voice feature which led to a change in a whole segment, since the change in this feature is phonemic.

The example here is the change of a sound from being voiced into a voiceless sound in the word slaepde from Old English.

The word slaepde had the $p d$ cluster -i.e. a voiceless sound followed by a voiced one. The sound/p/is [+voiceless, + plosive, and +aspirated], while/d/is [-aspirated, +voice, and + plosive]. For the sake of ease of articulation, the first sound $/ \mathrm{p} / \mathrm{affected}$ the $/ \mathrm{d} / \mathrm{sound}$. So, the $/ \mathrm{d} /$ sound came to be pronounced/t/which is [+aspirated, - voiced, and + plosive]. As we noticed above, $/ \mathrm{p} /$ the voiceless sound affected the following sound/d/in the feature of voicing.

\section{CONCLUSION}

The evidence to prove the systematicity of sound change and the significant role of $i$-umlaut on this change has been the main concern of this paper. Findings show that sound change begins as a subtle alteration in the sound pattern in a particular phonetic environment. The linguistic processes -underlying such phonetically conditioned change- are identical to the ones found in the phonology of currently spoken languages. The application of such process usually brings about an articulatory simplification, and over time significant changes in the phonology of a language can result which- in turn- can affect morphology through the loss of inflections.

\section{REFERENCES}

Algeo. J. (2009) The Origins and development of the English Language, USA: Wadsworth.

Barber, C. (1993) The English language: a historical introduction, Cambridge: Cambridge University Press

Campbell, L. (2004) Historical Linguistics: An Introduction, Edinburgh University press 2004.

Crosswhite, K. (2001), Vowel Reduction in Optimality Theo$r y$, New York: Routledge.

Crowley, T. (1992) An Introduction to Historical Linguistics: Oxford, Oxford University Press.

Crystal, D (1995). Cambridge Encyclopedia of the English Language. New York: Cambridge University Press.

Katamba. F. (1995) Historical Linguistics: The study of Language Change, London: Longman.

Lass, R. (1975), Old English Phonology. New York: Cambridge University Press.

Pyles, T. and Algeo, J. (1993) The Origins and development of the English Language, USA: Harcourt. 